\title{
Modeling gas-rock-water interactions in carbon dioxide storage capacity assessment: a case study of Jurassic sandstones in Poland
}

\author{
K. Labus $\cdot$ R. Tarkowski $\cdot$ M. Wdowin
}

Received: 20 February 2014 / Revised: 20 June 2014/ Accepted: 9 July 2014/ Published online: 8 August 2014

(C) The Author(s) 2014. This article is published with open access at Springerlink.com

\begin{abstract}
This paper presents the results of the modeling of gas-rock-water interactions for reservoir formation of one of potential geological carbon dioxide storage sites in the Polish Lowlands (Chabowo Anticline). The modeling performed with the use of a geochemical simulator was preceded by mineralogic-petrographical and petrophysical analysis of sandstones sampled together with pore water at the depths of $856-857$ and $1,240-1,241 \mathrm{~m}$. The study focused on determining the changes in rock matrix and reservoir parameters that take place as a result of carbon dioxide injection, and on the assessment of the formation suitability for carbon dioxide storage. The results have shown that in the analyzed gas-rock-water systems, in the modeled period of 20,000 years, the minerals able to trap carbon dioxide are calcite and dolomite. Mineral-trapping capacity of carbon dioxide, calculated for the sandstones considered, equals to 9.19 and $12.0 \mathrm{~kg}$ per one cubic meter of the formation.
\end{abstract}

Keywords Carbon dioxide storage $\cdot$ Hydrogeochemical modeling $\cdot$ Gas-rock-water interactions $\cdot$ Sandstone aquifer

\footnotetext{
K. Labus $(\square)$

Institute for Applied Geology, Silesian University of

Technology, 2 Akademicka St., 44-100 Gliwice, Poland

e-mail: klabus@o2.pl

R. Tarkowski · M. Wdowin

Mineral and Energy Economy Research Institute of the Polish

Academy of Sciences, 7 Wybickiego St., 31-261 Kraków,

Poland
}

\section{Introduction}

Geological storage of carbon dioxide $\left(\mathrm{CO}_{2}\right)$ is one of the options of greenhouse gas mitigation as it reduces the release rate of $\mathrm{CO}_{2}$ to the atmosphere (e.g., Holloway 2004). After the injection of $\mathrm{CO}_{2}$ into the subsurface, this gas can be trapped by several mechanisms: structural and stratigraphic trapping, residual $\mathrm{CO}_{2}$ trapping, solubility trapping and mineral trapping (Bachu et al. 2007). In mineral trapping, $\mathrm{CO}_{2}$ is bound by precipitating new carbonate minerals, and the storage potential depends on the temperature, pressure and the characteristics of aquifer formation, such as the mineralogy of the reservoir rock and the chemical composition of the brine. The kinetics of potential trapping reactions is also controlled by the specific surface of the minerals (the contact between skeletal grains and brine with dissolved $\mathrm{CO}_{2}$ ) and the flow rate of fluids through the pore space. With regard to chemical reactions, the siliciclastic rocks (in particular calcium-, magnesium- or iron-rich reservoirs) are favored over carbonate ones, as they present higher capacity of $\mathrm{CO}_{2}$ mineral trapping (Gunter et al. 1993). Mineral trapping is described as the safest mechanism in long-term storage of carbon dioxide (Metz et al. 2005); however, the time required for mineral precipitation is considerable, ranging from tens to thousands of years (Perkins and Gunter 1995). As a result of solubility trapping, $\mathrm{CO}_{2}$ is dissolved in the formation water (Koide et al. 1992). This phenomenon is strongly time-dependent (Bachu et al. 1994). On the other hand, $\mathrm{CO}_{2}$ solubility increases with pressure and decreases with temperature and salinity of the formation water. Dissolving $\mathrm{CO}_{2}$ into the formation water triggers the process of convective mixing, which is much more efficient than diffusive mixing, and crucial for solubility trapping, as it 
accelerates the overall dissolution of the $\mathrm{CO}_{2}$ into the pore water.

Saline aquifers are promising for geological storage of $\mathrm{CO}_{2}$ because of their storage potential and limited suitability for other uses (Hendriks and Blok 2004; Koide et al. 1992; Tarkowski and Wdowin 2011; Wdowin et al. 2013).

Geochemical monitoring of deep underground fluids is a basic procedure used to investigate the variations in fluid composition caused by $\mathrm{CO}_{2}$ injection and water-rock interactions, and to track the fate of the injected $\mathrm{CO}_{2}$ plume. Furthermore, the geochemical results are applied to carry out numerical modeling of deep geochemical processes (through thermodynamic database, saturation indexes, activities and speciation calculations of liquid phase) to evaluate theoretical reservoir equilibrium conditions among several phases and to reconstruct physico-chemical variations of different phases at non-equilibrium conditions on the basis of kinetically controlled reactions (e.g., Cantucci et al. 2009; Marini 2007). Therefore, in general, geochemical modeling is a helpful tool to assess the geochemical behavior of $\mathrm{CO}_{2}$ in saline aquifer, including its dissolution in brine, and interactions with minerals, etc. (Trémosa et al. 2014), which allows to determine the suitability of geological structures for $\mathrm{CO}_{2}$ storage (Labus et al. 2010). So far, numerous software packages were used for this purpose: e.g., PHREEQC (see: Tarkowski 2010; Van Pham et al. 2012), TOUGHREACT (Okuyama et al. 2013; Xu et al. 2006), CHILLER, SOLVEQ (Reed 1998; Rosenbauer et al. 2005), Geochemist's Workbench (Labus and Bujok 2011; Labus et al. 2010; Tarkowski et al. 2011; Zerai et al. 2006). The input data for geochemical modeling should include the following: formation temperature and pressure, petrophysical and petrological parameters of reservoir and cap rock, kinetic parameters of minerals, chemical data of pore fluids and the time of reaction.

In order to represent the different estimations made during calculations of carbon dioxide storage capacity, we can apply a techno-economic resource pyramid (Bradshaw et al. 2007) considering 4 technical and economic categories: total pore volume, prospective storage capacity, contingent capacity and operational storage capacitycharacterized by different storage volumes and assessment certainty (CO2CRC 2008). Another version of the resource pyramid considers the relationships between trap types, trapping mechanisms and the time needed for a given trapping mechanism to be effective (Bradshaw et al. 2007).

A simplified method of calculation the $\mathrm{CO}_{2}$ storage capacity in saline aquifers- $\mathrm{G}_{\mathrm{CO} 2}$-was presented in DOE (2012):

$G_{\mathrm{CO}_{2}}=A \cdot h_{\mathrm{g}} \cdot \phi_{\mathrm{tot}} \cdot \rho \cdot E$

where $A$-area of a region assessed for $\mathrm{CO}_{2}$ storage $\left[L^{2}\right]$, $h_{\mathrm{g}}$-thickness of aquifer formation $[L], \phi_{\text {tot }}$-average total porosity of the aquifer $\left[L^{3} / L^{3}\right], \rho-\mathrm{CO}_{2}$ density at pressure and temperature of storage site $\left[M / \mathrm{L}^{3}\right], \mathrm{E}-\mathrm{CO}_{2}$ storage efficiency-fraction of the total pore space that is filled with $\mathrm{CO}_{2}\left[L^{3} / L^{3}\right] ; L$-length, $M$-mass.

Bachu et al. (2007) proposed a much more precise calculation method, based on the assumption, that the trapping mechanisms are interdependent, and their effects should be combined to obtain the value of carbon dioxide trapping. The following components of storage capacity were distinguished according to this methodology: in structural and stratigraphic traps, in residual-gas traps, in solubility traps, in hydrodynamic traps and in mineral traps.

This paper presents the results of $\mathrm{CO}_{2}$ storage capacity evaluation in solubility and mineral traps, based on geochemical modeling for Chabowo Anticline-one of important, potential geological formations suitable for underground storage of carbon dioxide in the Polish Lowlands. The Chabowo structure is of interest to Dolna Odra power plant (electric power installed 1,742 MWe), located $50 \mathrm{~km}$ away from it, and to Gorzów Heat and Power Plant (97.5 MWe and $220 \mathrm{MWt}$ ) at $100 \mathrm{~km}$ distance. The input data for the modeling were obtained by petrophysical and mineralogic-petrographical analysis as well as by pore water analysis of the reservoir rock of Chabowo Anticline.

The research was conducted in 2013, within the framework of collaboration between the Institute for Applied Geology, Silesian University of TechnologyGliwice, and the Mineral and Energy Economy Research Institute of the Polish Academy of Sciences-Kraków.

\section{Materials and methods}

Chabowo Anticline is located approximately $15 \mathrm{~km}$ ESE of Gryfino-Fig. 1. It was explored by three boreholes: Chabowo 1, Chabowo 2 and Chabowo 3, and by semidetailed reflection seismic survey. Geochemical modeling for the structure was performed based on 2 sandstone (reservoir rock) samples, taken at the depths of 856-857 and 1,240-1,241 m b.s.l. from Chabowo 1 and Chabowo 3 wells, respectively (Table 1). Analyzed samples of sandstone represent reservoir levels of the Lower JurassicUpper Pliensbachian (Komorowo Formation)-Fig. 2 (Tarkowski 2010). The percentage of sandstones in the Beds of Komorowo Formation ranges from 61 to $84 \%$. Their effective porosity reaches $21.55 \%$ and permeability-540-800 mD. Pumping tests have shown discharge rates of $14.4-14.73 \mathrm{~m}^{3} / \mathrm{h}$ of brines, representing a chloride-sodium class I type, of TDS (total dissolved solids) within the range of $67-87.5 \mathrm{~g} / \mathrm{l}$, and the temperature ranging from 40 to $46{ }^{\circ} \mathrm{C}$. Lower Jurassic Beds of Komorowo Formation are overlain by the Beds Gryfice 


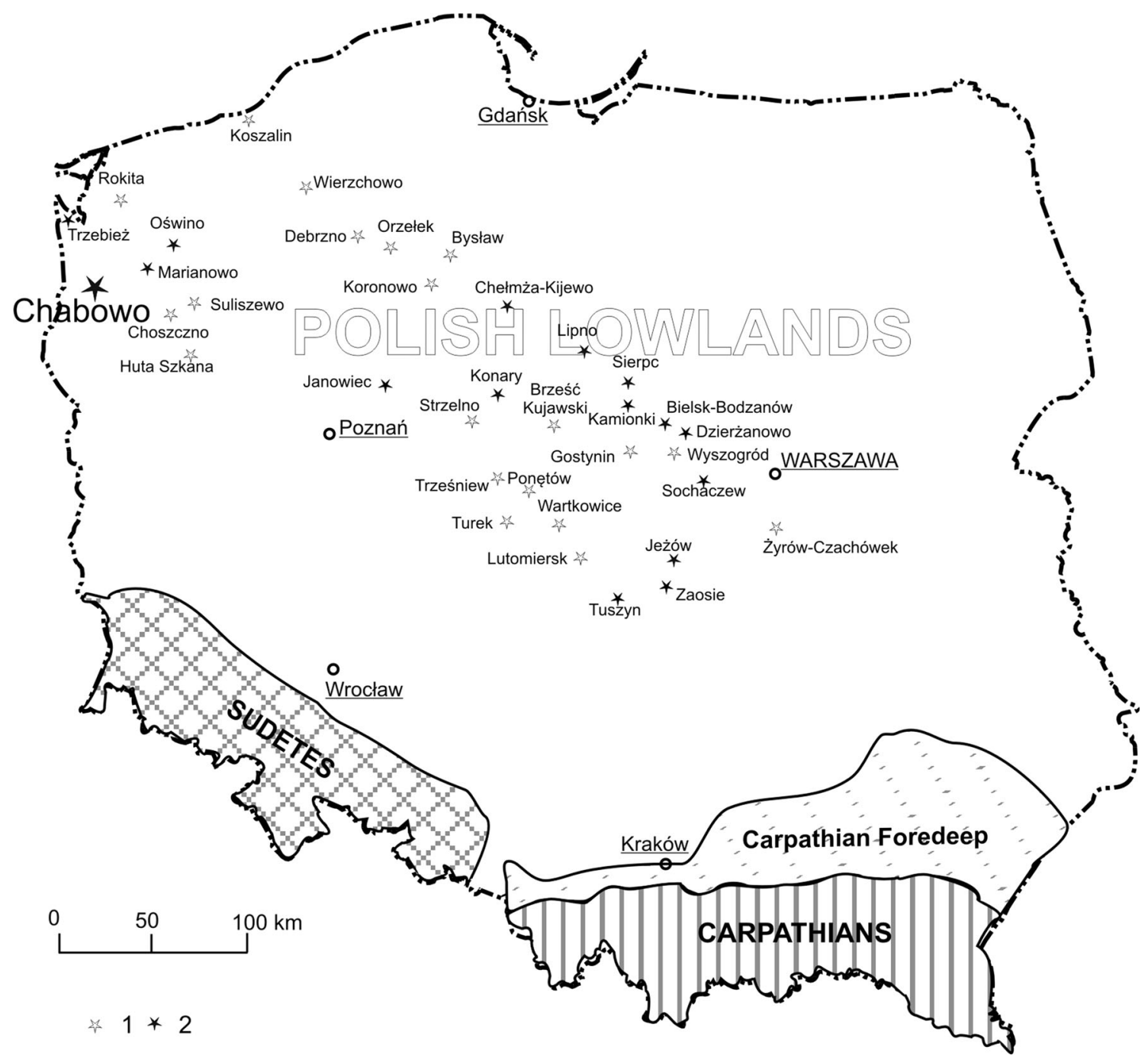

Fig. 1 Potential geological $\mathrm{CO}_{2}$ storage sites in the Polish Lowlands. Explanations: 1 structures with one level of $\mathrm{CO}_{2}$ storage, 2 structures with two levels of $\mathrm{CO}_{2}$ storage

Formation (complex of claystones interbedded by sandy mudstone) (Tarkowski et al. 2014).

The analyzed reservoir rocks (Chabowo 1-856-857 m and Chabowo 3-1,240-1,241 $\mathrm{m}$ ) are represented by moderately and poorly sorted, highly porous quartz sandstones. They are of medium and fine grain size $200-500 \mu \mathrm{m}$ in diameter, but also bigger grains up to $1,500 \mu \mathrm{m}$ can be found. Their contact-porous cement is composed mainly of clay minerals. Rock matrix typically contains quartz, lesser amounts of feldspars and micas. In sandstones from the deeper horizon, of 1,240-1241 m b.s.l, significant quantities of pyrite were also observedTable 1.

Scanning electron microscopy and X-ray diffraction were used in the identification of mineral phases. The observations in transmitted light and planimetric analysis with JENALAB Karl Zeiss Jena polarizing microscope were also made in order to assess the percentage composition of mineral assemblages.

$\mathrm{X}$-ray diffraction analysis (XRD) was performed by means of a powder X-ray diffractometer Philips X'pert APD with PW 3020 goniometer and a copper lamp as well graphite monochromator. The analysis was carried out in the angular range of 5-65 20. For diffraction data processing, the Philips X'Pert software was used. The identification of mineral phases was carried out based on JCPDS-ICDD database.

To observe alterations in the rock matrix, the FEI Quanta 200 FEG scanning electron microscope, equipped with backscattered electron detector and EDS EDAX microprobe analyzer were used.

As the accuracy of image analysis could be insufficient in the case of porosimetric properties examination in sandstones (Labus 2001), the porosity and specific surface 
Table 1 Basic parameters of rock samples from the Chabowo 1 and Chabowo 3 wells, and kinetic rate parameters at $25{ }^{\circ} \mathrm{C}$ (data from Palandri and Kharaka (2004)

\begin{tabular}{|c|c|c|c|c|c|c|}
\hline & Sample no. & 1 & & & 2 & \\
\hline & Well & Chabowo & & & Chabowo & \\
\hline & Depth $[\mathrm{m}]$ & $856-857$ & & & $1,240-1,2$ & \\
\hline & Mean capillary diameter $[\mu \mathrm{m}]$ & 1.5629 & & & 0.6968 & \\
\hline & Porosity from porosimeter [\%] & 23.8 & & & 17.0 & \\
\hline & Kinetic rate $\mathrm{k}_{25}\left[\mathrm{~mol} / \mathrm{m}^{2} \mathrm{~s}^{-1}\right]$ & Composition [\% vol.] & $\mathrm{SSM}\left[\mathrm{m}^{2} / \mathrm{g}\right]$ & Com & n [ $\%$ vol. $]$ & $\mathrm{SSM}\left[\mathrm{m}^{2} / \mathrm{g}\right]$ \\
\hline Quartz & $1.02 \cdot \mathrm{e}-14$ & 68.2 & $4.53 \cdot e-6$ & 62.8 & & $7.55 \cdot e-6$ \\
\hline Chalcedony & $4.90 \cdot e-13$ & 4.0 & $6.87 \cdot e-5$ & 1.4 & & $6.87 \cdot e-5$ \\
\hline Illite & $1.66 \cdot e-13$ & 4.3 & $1.09 \cdot \mathrm{e}-3$ & 6.9 & & $1.09 \cdot \mathrm{e}-3$ \\
\hline Annite & $3.16 \cdot e-11$ & 0.3 & $9.04 \cdot e-5$ & 0.4 & & $9.04 \cdot e-5$ \\
\hline Muscovite & $2.82 \cdot \mathrm{e}-14$ & 1.0 & $1.06 \cdot e-4$ & 0.6 & & $1.06 \cdot \mathrm{e}-4$ \\
\hline K-feldspar & $3.89 \cdot e-13$ & 8.0 & $4.69 \cdot e-6$ & 5.8 & & $7.82 \cdot e-6$ \\
\hline Albite & $2.75 \cdot e-13$ & 4.0 & $4.59 \cdot e-6$ & 2.9 & & $7.45 \cdot e-6$ \\
\hline Anorthite & $7.59 \cdot \mathrm{e}-10$ & 4.0 & $4.35 \cdot e-6$ & 2.9 & & $7.25 \cdot e-6$ \\
\hline Calcite & $1.55 \cdot \mathrm{e}-06$ & 4.2 & $6.71 \cdot e-6$ & 6.9 & & $6.71 \cdot e-6$ \\
\hline Goethite & $1.15 \cdot \mathrm{e}-08$ & 2.0 & $4.26 \cdot e-6$ & 1.4 & & $4.26 \cdot e-6$ \\
\hline Pyrite & $2.82 \cdot \mathrm{e}-05$ & - & - & 8.0 & & $7.98 \cdot e-6$ \\
\hline
\end{tabular}

SSM specific surface of analyzed minerals

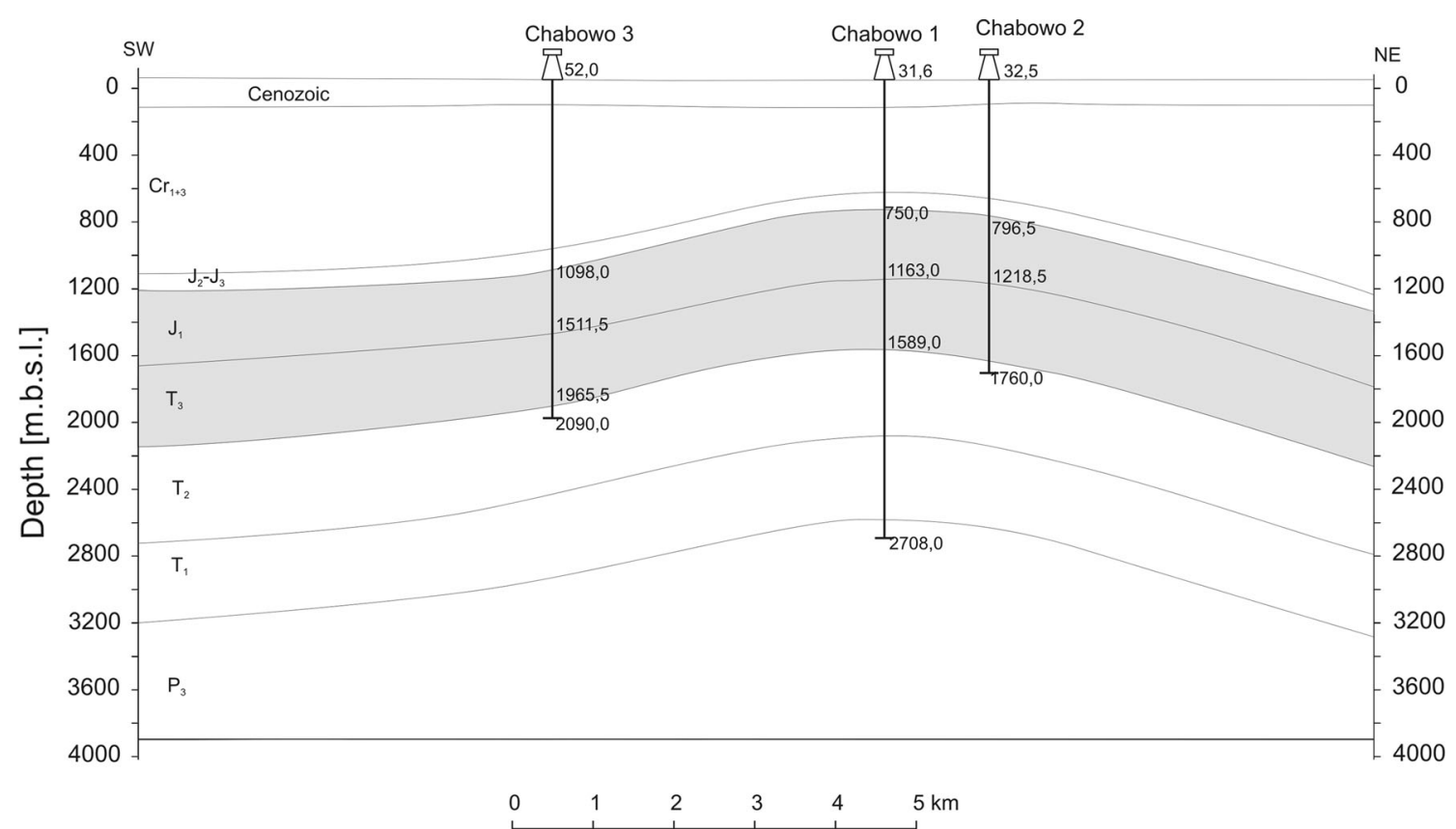

Fig. 2 Geological cross section of Chabowo Anticline (levels of $\mathrm{CO}_{2}$ storage marked in gray. Explanations: $P$ Permian, $T$ Triassic, $J$ Jurassic, $C r$ Cretaceous. (Tarkowski 2010)

were measured by means of mercury porosimetry. The AUTO PORE 9220 (Micromeritics) was applied at 30,000 psi maximum pressure, allowing for micropores detection.
Geochemical modeling, applying the methodology described in detail in Labus (2009) and Labus and Bujok (2011), was aimed at the assessment of storage capacity and the changes of rock matrix and reservoir parameters 
Table 2 Groundwater chemistry

\begin{tabular}{ll}
\hline Parameter & Value \\
\hline $\mathrm{pH}$ & 7.0 \\
Specific density [kg/l] & 1.0586 \\
$\mathrm{TDS}[\mathrm{g} / \mathrm{l}]$ & 85.526 \\
$\mathrm{Cl}^{-}[\mathrm{mg} / \mathrm{l}]$ & 50700 \\
$\mathrm{SO}_{4}{ }^{2-}[\mathrm{mg} / \mathrm{l}]$ & 728 \\
$\mathrm{HCO}_{3}{ }^{-}[\mathrm{mg} / \mathrm{l}]$ & 110 \\
$\mathrm{Ca}^{2+}[\mathrm{mg} / \mathrm{l}]$ & 1178 \\
$\mathrm{Mg}^{2+}[\mathrm{mg} / \mathrm{l}]$ & 164 \\
$\mathrm{Na}^{+}[\mathrm{mg} / \mathrm{l}]$ & 29500 \\
$\mathrm{~K}^{+}[\mathrm{mg} / \mathrm{l}]$ & 211 \\
\hline
\end{tabular}

that could occur due to $\mathrm{CO}_{2}$ injection. The simulations were performed with the use of Geochemist's Workbench Pro 9.0. package in two stages: the first-simulation of immediate textural and mineralogical changes in the aquifer impacted by the beginning of $\mathrm{CO}_{2}$ injection
(100 days), the second-long-term effects of the storage (20,000 years). Kinetic rate constants, conforming to general Arrhenius-type rate equation for the minerals involved in modeled reactions (Table 1), were taken from Palandri and Kharaka (2004) and were recalculated for the formation temperatures: accepted as $40.0{ }^{\circ} \mathrm{C}$ for the depth interval $856-857 \mathrm{~m}$, and as $46.0^{\circ} \mathrm{C}$ for $1,240-1,241 \mathrm{~m}$. Pore water composition used in the modeling is presented in the Table 2. It was also assumed that under the injection pressure ( $85 \%$ of lithostatic pressure), $\mathrm{CO}_{2}$ pressure reaches 176.8 and 258.0 bar, respectively. Gas fugacities$\mathrm{f}_{\mathrm{CO} 2}$ equal to 68.4 and 86.9 bar, were calculated after Duan et al. (2006), using online calculator of The Duan Group.

Specific surface area of minerals (SSM) required for the simulation of kinetic reactions was calculated based on spherical grains model, using the radius (calculated based on image analysis discussed in Labus 2001), molar volume and molecular weight of each of mineral, according to the following formula:
Fig. 3 Changes in: $\mathrm{pH}$, quantity of carbonate minerals and porosity on the stage of $\mathrm{CO}_{2}$ injection-sample 1
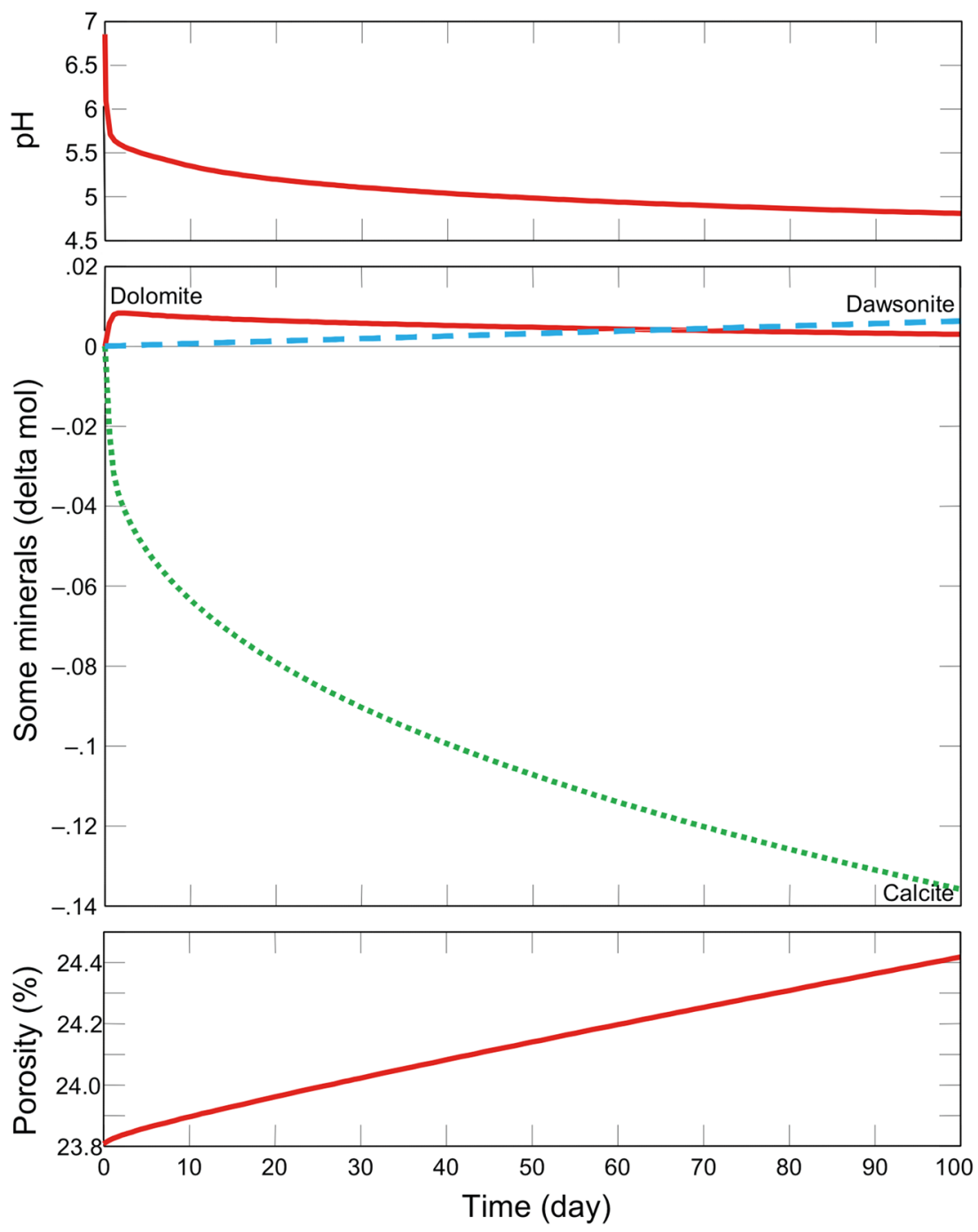
Fig. 4 Changes in: $\mathrm{pH}$, quantity of carbonate minerals and porosity since the termination of $\mathrm{CO}_{2}$ injection-sample 1

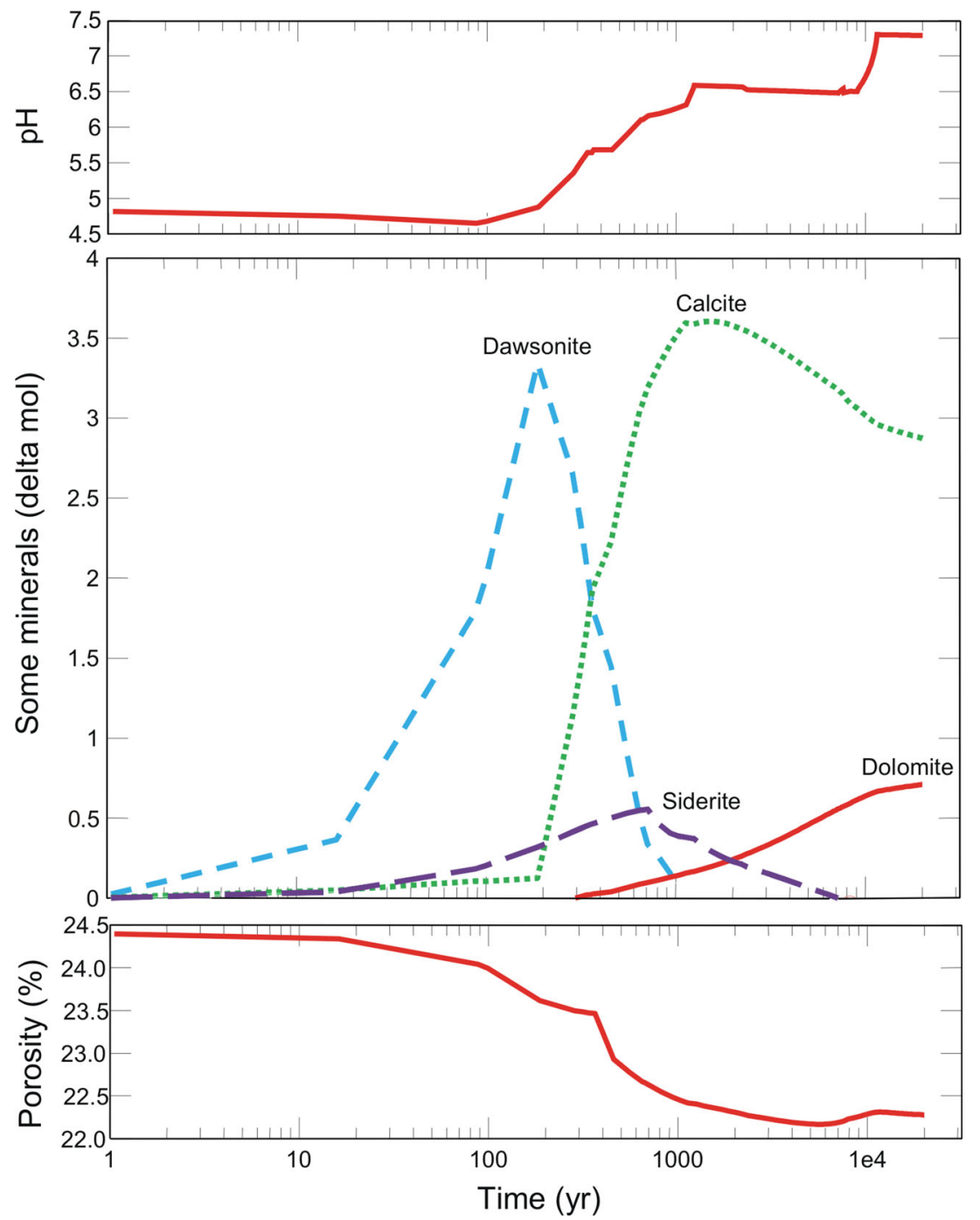

$\mathrm{SSM}=\frac{A \cdot v}{V \cdot \mathrm{MW}}$

where $A$-sphere area $\left[\mathrm{m}^{2}\right], v$-molar volume $\left[\mathrm{m}^{3} / \mathrm{mol}\right], V-$ sphere volume $\left[\mathrm{m}^{3}\right]$ and MW-molecular weight $[\mathrm{g} / \mathrm{mol}]$ of a given mineral phase. The values of the specific surface areas used in calculations are presented in the Table 1 .

\section{Results and discussion}

The results of modeling for Chabowo 1 Well

During the first stage, lasting for 100 days, the $\mathrm{CO}_{2}$ injection causes an increase of gas fugacity to the assumed value: $\mathrm{f}_{\mathrm{CO} 2}-68,4$ bar. In effect, we can observe a significant elevation of $\mathrm{CO}_{2}(\mathrm{aq})$ and $\mathrm{HCO}_{3}{ }^{-}$concentrations, to 1.296 and $0.076 \mathrm{~mol} / 1$, respectively, and a drop of pore water's $\mathrm{pH}$ to $4.82 \mathrm{pH}$ (Fig. 3). The increase of porosity by
0.6 percent points (pp) to $24.4 \%$, barely influencing the injected fluid penetration into the aquifer, is mainly controlled by the dissolution of calcite. The changes in the quantity of carbonates at the stage of $\mathrm{CO}_{2}$ injection are shown in the Fig. 3.

In the second stage, within a period of approximately 200 years, $\mathrm{CO}_{2}$ fugacity drops to the value of about 1 bar. The $\mathrm{CO}_{2}(\mathrm{aq})$ and $\mathrm{HCO}_{3}$ concentrations fall significantly to $5.4 \cdot 10^{-6}$ and $9.4 \cdot 10^{-5} \mathrm{~mol} / \mathrm{l}$, respectively; rising of $\mathrm{pH}$ reaches the value of 7.29 . The porosity falls to $22.3 \%$ (1.5 pp lower compared to the primary porosity) causing a slight permeability damage of the aquifer (Fig. 4).

For the first 200 years of the second stage, the processes of dawsonite and siderite precipitation (Fig. 4) are mainly responsible for the porosity decrease. Subsequently, both these minerals undergo dissolution, triggering crystallization of calcite and dolomite, respectively. Finally, $2.87 \mathrm{~mol}$ of secondary calcite and $0.71 \mathrm{~mol}$ dolomite precipitate per unit volume of modeled aquifer rock-UVR-equal to 
Fig. 5 Changes in: $\mathrm{pH}$, quantity of carbonate minerals and porosity on the stage of $\mathrm{CO}_{2}$ injection-sample 2
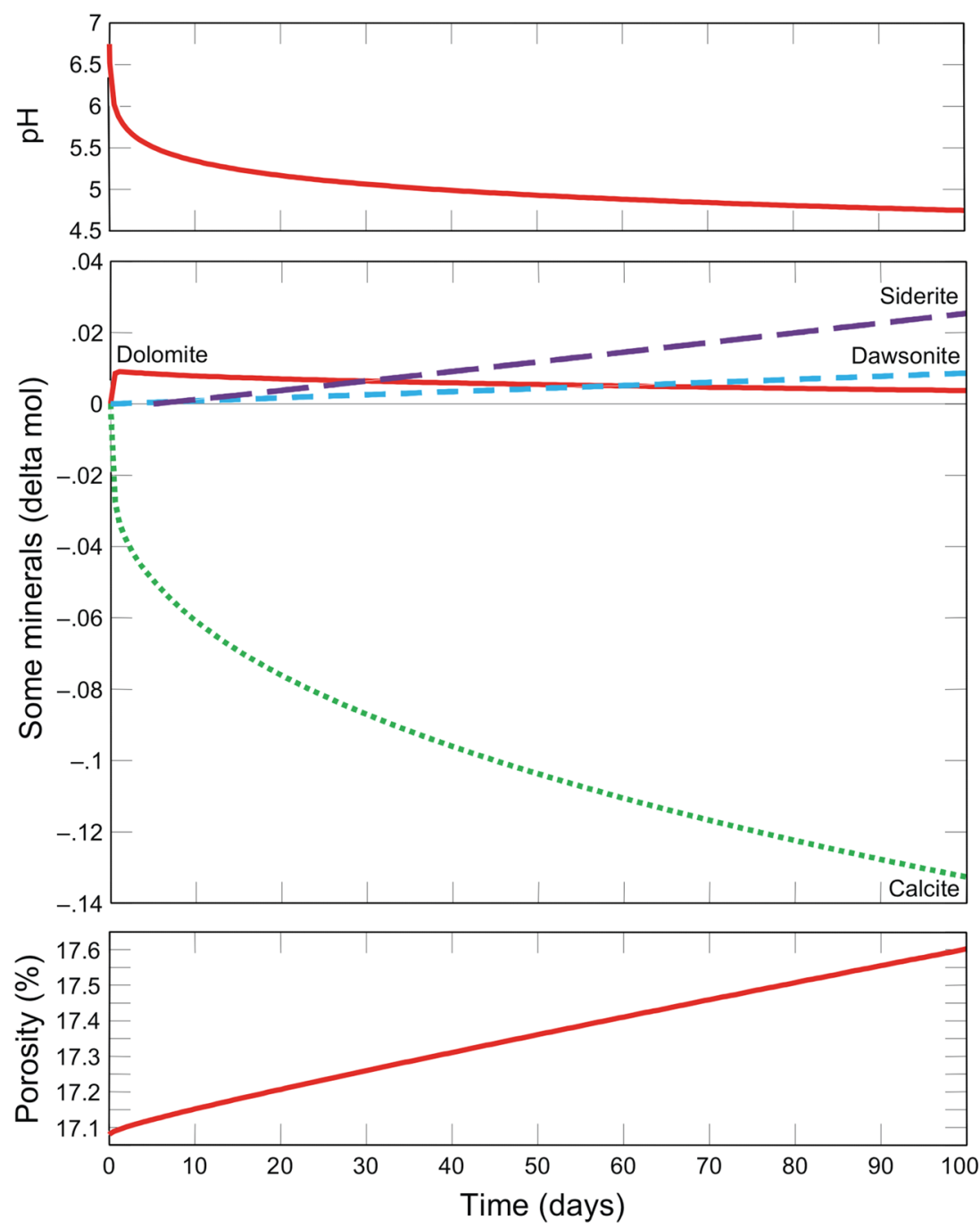

$0,01 \mathrm{~m}^{3}$, within $20 \mathrm{ka}(20,000$ years $)$ of simulated $\mathrm{CO}_{2}$ aquifer storage.

The results of modeling for Chabowo 3 Well

The gas-rock-water interactions were modeled for sample no. 2 as well. The main mechanisms playing the role during the first stage-the $\mathrm{CO}_{2}$ injection-are similar to the ones working in the case of sample no. 1 . The $\mathrm{pH}$ of pore waters drops to $4.75 \mathrm{pH}$ (Fig. 5). We can observe siderite precipitation, which is connected with the dissolution of goethite and pyrite. A small increase of porosity is also noticed, mainly due to the significant volume of degraded calcite (Fig. 5).

The second stage is characterized by a sudden drop of fugacity, a stepwise decrease of $\mathrm{CO}_{2}(\mathrm{aq})$ and $\mathrm{HCO}_{3}$ concentrations, and a quick growth of $\mathrm{pH}$ (Fig. 6). The porosity decreases by $1.2 \mathrm{pp}$ (to $15.8 \%$, compared to the primary value-17\%), in favor of the rock insulating properties. Calcite (1.79 mol per UVR) and dolomite
(0.69 mol per UVR) are the precipitating mineral phases that are able to efficiently trap injected $\mathrm{CO}_{2}$ (Fig. 6). It should be noted that some amounts of siderite that were already formed at the stage of injection-about $0.2 \mathrm{~mol}$, are completely degraded in the stage II.

Storage capacity calculations

The trapping capacity of the formations analyzed (Table 3) was calculated under the following assumptions: The unit volume of modeled aquifer rock-UVR-is equal to $0,01 \mathrm{~m}^{3}$, and the primary porosity value (prior to the storage) is equal to $\mathrm{n}_{\mathrm{p}}$. Then, the rock matrix volume measured in UVR in $1 \mathrm{~m}^{3}$ of formation amounts to $100\left(1-n_{\mathrm{p}}\right)$. According to the modeled reactions, a certain quantity of carbonate minerals dissolves or precipitates per each UVR. On this basis, the $\mathrm{CO}_{2}$ balance and eventually the quantity of $\mathrm{CO}_{2}$ trapped in mineral phases is calculated. Modeled chemical constitution of pore water allows for the 
Fig. 6 Changes in: $\mathrm{f}_{\mathrm{CO} 2}$, concentrations of $\mathrm{CO}_{2}(\mathrm{aq})$ and $\mathrm{HCO}_{3}{ }^{-}$, $\mathrm{pH}$, quantity of carbonate minerals and porosity since the termination of $\mathrm{CO}_{2}$ injection-sample 2
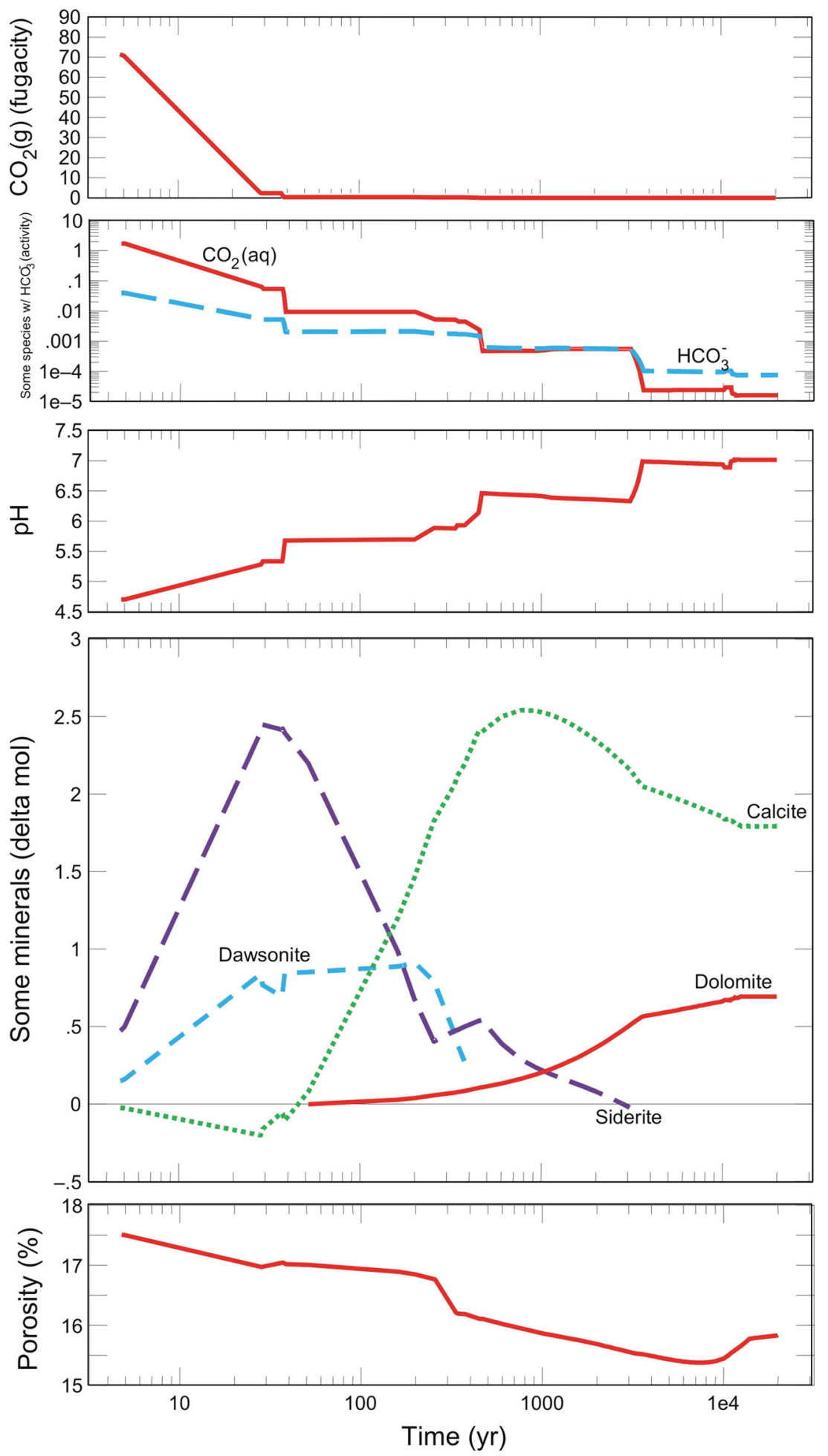

calculation of the quantity of $\mathrm{CO}_{2}$ trapped in the form of the solution. After simulated $20 \mathrm{ka}$ of storage, the final porosity is $n_{\mathrm{f}}$. Pore space is assumed to be filled with pore water of known (modeled) concentrations of $\mathrm{CO}_{2}$-containing aqueous species: e.g., $\mathrm{HCO}_{3}{ }^{-}, \mathrm{CO}_{2}(\mathrm{aq}), \mathrm{CO}_{3}{ }^{2-}$, $\mathrm{NaHCO}_{3}$, etc. (expressed in molHCO${ }_{3}^{-} / 1$ ).
An example for No. 1 sample is given below: The primary porosity $-n_{\mathrm{p}}$ is about $23.8 \%$, thus $1 \mathrm{~m}^{3}$ of formation contains 76.2 UVRs. For each UVR, $2.87 \mathrm{~mol}$ calcite and $0.71 \mathrm{~mol}$ dolomite precipitate, trapping $3.58 \mathrm{~mol}$ of $\mathrm{CO}_{2}$. After $20 \mathrm{ka}$ of storage, the final porosity $-n_{\mathrm{f}}$ is equal to $22.3 \%$; therefore, $1 \mathrm{~m}^{3}$ of formation is assumed to contain 
Table 3 Mineral and solubility trapping capacity of analyzed formations

\begin{tabular}{|c|c|c|c|}
\hline & Sample no. & 1 & 2 \\
\hline \multirow[t]{2}{*}{ Porosity (\%) } & $\mathrm{n}_{\mathrm{p}}$ - primary $-0 \mathrm{ka}$ & 23.8 & 17.0 \\
\hline & $\mathrm{n}_{\mathrm{f}}$-final-20 ka & 22.8 & 15.8 \\
\hline Precipitating & Calcite & 2.87 & 1.79 \\
\hline Minerals [mol/UVR] & Dolomite & 0.71 & 0.69 \\
\hline $\mathrm{CO}_{2}$ & mol/UVR & 3.58 & 2.48 \\
\hline Mineral trapping ${ }^{*}$ & {$\left[\mathrm{~kg} \mathrm{CO} 2 / \mathrm{m}^{3}\right]$} & 12.16 & 9.19 \\
\hline $\mathrm{CO}_{2}$ & $\mathrm{~mol} / \mathrm{l}$ & $1.8 \cdot 10^{-4}$ & $4.2 \cdot 10^{-4}$ \\
\hline Solubility trapping ${ }^{*}$ & {$\left[\mathrm{~kg} \mathrm{CO} / 2 \mathrm{~m}^{3}\right]$} & $1.77 \cdot 10^{-3}$ & $2.92 \cdot 10^{-3}$ \\
\hline $\operatorname{SUM}\left[\mathrm{kg} \mathrm{CO} / \mathrm{m}^{3}\right]$ & & 12.162 & 9.193 \\
\hline
\end{tabular}

Explanations in the text

$0.223 \mathrm{~m}^{3}$ of pore water. The fluid contains $1.8 \cdot 10^{-4} \mathrm{~mol}$ $\mathrm{HCO}_{3}{ }^{-} / 1$, therefore, the calculated solution trapping for the formation is $1.77 \cdot 10^{-6} \mathrm{~kg} \mathrm{CO}_{2} / 1$.

Mineral trapping is strongly dependent on the thermodynamic regime of the reservoir as well as on chemical composition of formation waters, flow rate of fluids, and mineralogical composition and reactive surface of the rock matrix (Gunter et al. 2004). The reactive surface size of a rock depends on grain and pore size distribution, and on the intensity of grain contacts. The flow rate may vary depending on hydraulic gradients, permeability of rocks and water viscosity (controlled by temperature and water mineralization, and the pressure to some extent). In the context of such complex processes involved and the precision of the data required to assess the amounts of secondary minerals precipitation, any exact regional-scale estimations of $\mathrm{CO}_{2}$ storage capacity are impossible. Only small-area scale estimates of the amount of mineral-trapped $\mathrm{CO}_{2}$, based on numerical simulations, supported by experiments and field data from natural analogs, are feasible. The $\mathrm{CO}_{2}$ mineral-trapping capacity of unitary rock volume, within the modeled $20 \mathrm{ka}$ period, is much more efficient than storage through solubility trapping; however, the mineral trapping process is significantly slower (e.g., Xu et al. 2003).

\section{Conclusion}

In the analyzed gas-rock-water systems, within the modeled period of 20,000 years, the minerals able to trap $\mathrm{CO}_{2}$ are calcite and dolomite. Mineral-trapping capacity of 9.19 and $12.16 \mathrm{~kg} \mathrm{CO}_{2} / \mathrm{m}^{3}$ (Table 3) calculated for the Chabowo Anticline sandstones is almost two to four times higher than the values described in Labus and Bujok (2011) for Carboniferous sandstone aquifers of the Upper Silesian Coal Basin. It is, however, comparable to the data presented by
Balashov et al. (2013), for sandstone, where $30 \%$ out of $34.5 \mathrm{~kg} \mathrm{CO}_{2}$ stored per $\mathrm{m}^{3}$ of rock precipitated as calcite. Similar capacities, reaching $10.3 \mathrm{~kg} \mathrm{CO} / \mathrm{m}^{3}$, were also assessed for Jurassic aquifers of potential storage site within the Bełchatów area (Labus et al. 2010), while for a glauconitic sandstone from Alberta Sedimentary Basin-Xu et al. (2004) reported $17 \mathrm{~kg}$ per $\mathrm{m}^{3}$ of formation.

Under the conditions of Chabowo Anticline sandstones, the solubility trapping performance (up to $2.92 \cdot 10^{-3} \mathrm{~kg}$ $\mathrm{CO}_{2} / \mathrm{m}^{3}$ ) is negligible compared to those of mineral trapping. Also the changes in rock porosity, observed due to the simulation, are insignificant in the context of permeability damage of the sandstones analyzed.

The presented results proved the occurrence of high storage capacity horizons within the analyzed area. More exact assessment of the geological space suitability for $\mathrm{CO}_{2}$ storage requires, however, the determination of variability of petrophysical and petrological properties and accurate tectonic-structural analysis of the formation.

Acknowledgments This work was funded by the National Science Centre, according to the decisions No. DEC-2011/03/B/ST10/04340 and DEC-2012/05/B/ST10/00416. The authors are grateful to the three anonymous reviewers whose comments and suggestions helped improve and clarify this manuscript.

Open Access This article is distributed under the terms of the Creative Commons Attribution License which permits any use, distribution, and reproduction in any medium, provided the original author(s) and the source are credited.

\section{References}

Bachu S, Gunter WD, Perkins EH (1994) Aquifer disposal of $\mathrm{CO}_{2}$ : hydrodynamic and mineral trapping. Energy Convers Manag 35(4):269-279

Bachu S, Bonijoly D, Bradshaw J, Burruss R, Holloway S, Christensen NP, Mathiassen OM (2007) $\mathrm{CO}_{2}$ storage capacity estimation: methodology and gaps. Int J Greenh Gas Control 1:430-443

Balashov VN, Guthrie GD, Hakala JA, Rimstidt CL, Lopano JD, Brantley SL (2013) Predictive modeling of $\mathrm{CO}_{2}$ sequestration in deep saline sandstone reservoirs: impacts of geochemical kinetics. Appl Geochem 30:41-56

Bradshaw J, Bachu S, Bonijoly D, Burruss R, Holloway S, Christensen NP, Mathiassen OM (2007) $\mathrm{CO}_{2}$ storage capacity estimation: issues and development of standards. Int $\mathbf{J}$ Greenh Gas Control 1(1):62-68

Cantucci B, Montegrossi G, Vaselli O, Tassi F, Quattrocchi F, Perkins EH (2009) Geochemical modeling of $\mathrm{CO}_{2}$ storage in deep reservoirs: the Weyburn Project (Canada) case study. Chem Geol 265(1-2):181-197

CO2CRC (2008) Storage capacity estimation, site selection and characterisation for $\mathrm{CO}_{2}$ Storage Projects. Cooperative Research Centre for Greenhouse Gas Technologies, Canberra. CO2CRC Report No. RPT08-1001, p. 52

DOE (2012) The North American Carbon Storage Atlas: Appendix B-summary of methodologies used to estimate $\mathrm{CO}_{2}$ storage 
resource. http://www.netl.doe.gov/File\%20Library/Research/ Carbon\%20Seq/Reference\%20Shelf/NACSA2012.pdf. Accessed 12 June 2014

Duan ZH, Sun R, Zhu C, Chou IM (2006) An improved model for the calculation of $\mathrm{CO}_{2}$ solubility in aqueous solutions containing $\mathrm{Na}^{+}, \mathrm{K}^{+}, \mathrm{Ca}^{2+}, \mathrm{Mg}^{2+}, \mathrm{Cl}^{-}$, and $\mathrm{SO}_{4}{ }^{2-}$. Mar Chem 98:131-139

Gunter WD, Perkins EH, McCann TJ (1993) Aquifer disposal of $\mathrm{CO}_{2}$ rich gases: reaction design for added capacity. Energy Convers Manag 34(9-11):941-948

Gunter WD, Bachu S, Benson SM (2004) The role of hydrogeological and geochemical trapping in sedimentary basins for secure geological storage for carbon dioxide. In: Baines SJ, Worden RH (eds) Geological Storage of Carbon Dioxide. Geological Society Special Publication 233, London, pp 129-145

Hendriks CA, Blok K (2004) Underground storage of carbon dioxide. Energy Convers Manag 34(9-11):949-957

Holloway S (2004) Underground sequestration of carbon dioxide-a viable greenhouse gas mitigation option. Energy 30:2318-2333

Koide H, Tazaki Y, Noguchi Y, Nakayama S, Iijima M, Ito K, Shindo Y (1992) Subterranean containment and long-term storage of carbon dioxide in unused aquifers and in depleted natural gas reservoirs. Energy Convers Manag 33(5-8):619-626

Labus M (2001) Comparison of computer image analysis with mercury porosimetry in sandstone porosity measurement. Geol Q 45(1):75-79

Labus K (2009) Modeling hydrochemical effects of carbon dioxide sequestration in saline aquifers of the Upper Silesian Coal Basin. Monograph of the Silesian University of Technology 235, Gliwice, p 106

Labus $\mathrm{K}$, Bujok P (2011) $\mathrm{CO}_{2}$ mineral sequestration mechanisms and capacity of saline aquifers of the Upper Silesian Coal Basin (Central Europe)-modeling and experimental verification. Energy 36:4974-4982

Labus K, Tarkowski R, Wdowin M (2010) Assessment of $\mathrm{CO}_{2}$ sequestration capacity based on hydrogeochemical model of water-rock-gas interactions in the potential storage site within the Bełchatów area (Poland). Miner Resour Manag 26(2):69-84

Marini L (2007) Geological sequestration of carbon dioxide: thermodynamics, kinetics and reaction path modeling. Elsevier, Amsterdam

Metz B, Davidson O, Coninck H, Loos M, Meyer L (eds) (2005) Carbon dioxide capture and storage. The IPCC Special Report. Cambridge University Press, Cambridge, p 442

Okuyama Y, Norifumi TN, Munetake SM, Ajima S, Akasaka C (2013) Reactive transport simulation study of geochemical $\mathrm{CO}_{2}$ trapping on the Tokyo Bay model-with focus on the behavior of dawsonite. Appl Geochem 30:57-66

Palandri JL, Kharaka YK (2004) A compilation of rate parameters of water-mineral interaction kinetics for application to geochemical modeling. US Geological Survey. Open File Report 2004-1068, pp 1-64

Perkins EH, Gunter WD (1995) Aquifer disposal of $\mathrm{CO}_{2}$-rich greenhouse gases: modelling of water-rock reaction paths in a siliciclastic aquifer. In: Kharaka YK, Chudaev OV (eds)
Proceedings of the 8th International Symposium on water-rock interaction, Balkema, Rotterdam, pp 895-898

Reed MH (1998) Calculation of simultaneous chemical equilibria in aqueous-mineral-gas systems and its application to modeling hydrothermal processes. In: Richards J, Larson P (eds) Techniques in hydrothermal ore deposit geology. Reviews in economic geology 10:109-124

Rosenbauer RJ, Koksalan T, Palandri JL (2005) Experimental investigation of $\mathrm{CO}_{2}$-brine-reck interactions at elevated temperature and pressure: implications for $\mathrm{CO}_{2}$ sequestration in deep-saline aquifer. Fuel Process Technol 86:1581-1597

Tarkowski R (Ed.) (2010) Potential geological structures to $\mathrm{CO}_{2}$ storage in the Mesozoic Polish Lowlands (characteristics and ranking). Studies, Theses, Monographs of the MEERI PAS 164, Kraków, pp 138

Tarkowski R, Wdowin M (2011) Petrophysical and mineralogical research on the influence of $\mathrm{CO}_{2}$ injection on mesozoic reservoir and Caprocks from the Polish Lowlands. Oil Gas Sci Technol Rev IFP Energy Nouv 66(1):137-150

Tarkowski R, Wdowin M, Labus K (2011) Results of mineralogicpetrographical studies and numerical modeling of water-rock$\mathrm{CO}_{2}$ system of the potential storage site within the Belchatow area (Poland). Energy Proc 4:3450-3456

Tarkowski R, Dziewińska L, Marek S (2014) The characteristics of selected potential geological structures for $\mathrm{CO}_{2}$ underground storage in Mesozoic deposits of the Szczecin-Mogilno-Uniejów Trough. Studies, theses, monographs of the MEERI PAS, Kraków, pp 92

Trémosa J, Castillo C, Vong CQ, Kervévan C, Lassin A, Audigane P (2014) Long-term assessment of geochemical reactivity of $\mathrm{CO}_{2}$ storage in highly saline aquifers: application to Ketzin, In Salah and Snøhvit storage sites. Int J Greenh Gas Control 20:2-26

Van Pham TH, Aagaard P, Hellevang H (2012) On the potential for $\mathrm{CO}_{2}$ mineral storage in continental flood basalts-PHREEQC batch- and 1D diffusion-reaction simulations. Geochem Trans 13(5):2-12

Wdowin M, Tarkowski R, Franus W (2013) Supplementary studies of textural and mineralogical changes in reservoir and cap rocks from selected potential sites suitable for underground $\mathrm{CO}_{2}$ storage. Arab J Sci Eng. doi:10.1007/s13369-013-0862-0

Xu T, Apps JA, Pruess K (2003) Reactive geochemical transport simulation to study mineral trapping for $\mathrm{CO}_{2}$ disposal in deep arenaceous formations. J Geophys Res 108:2071-2084

$\mathrm{Xu}$ T, Apps JA, Pruess K (2004) Numerical simulation of $\mathrm{CO}_{2}$ disposal by mineral trapping in deep aquifers. Appl Geochem 19:917-936

$\mathrm{Xu}$ T, Sonnenthal EL, Spycher N, Pruess K (2006) TOURGHREACT: a simulation program for non-isothermal multiphase reactive geochemical transport in variably saturated geologic media. Comput Geosci 32:145-165

Zerai B, Saylor BZ, Matisoff G (2006) Computer simulation of $\mathrm{CO}_{2}$ trapped through mineral precipitation in the Rose Run Sandstone, Ohio. Appl Geochem 21:223-240 